\title{
The Adansonian Taxonomy of some Yellow Pigmented Marine Bacteria
}

\author{
BY G. D. FLOODGATE* AND P. R. HAYES $\dagger$ \\ Torry Research Station, Aberdeen
}

(Received 2 May 1962)

\begin{abstract}
SUMMARY
An Adansonian analysis of the features of 62 yellow pigmented marine bacteria, all but one of which were identified as Flavobacterium species by the workers who isolated them, revealed that 34 fell into one of two large pleista or groups; the rest fell into smaller pleista, or were the sole representative of their pleiston present. The possibility that these pleista approximate to various established genera is discussed.
\end{abstract}

\section{INTRODUCTION}

The genus Flavobacterium and the genus Cytophaga are placed in different Orders of the Class Schizomycetes by Bergey's Manual (1957). This would lead one to expect that it would be easy to distinguish the members of either genus from the members of the other. In fact, several workers have commented on the difficulty that is encountered in making this distinction. For example, Stanier (1947) found that a number of soil cytophagas formed short elements which morphologically closely resembled true bacteria. He commented that inspection of cultures with a predominance of short cells 'does not suggest that the organisms are myxobacteria; flexibility is not evident, and the motility of the individual cells is hard to detect; the only indicative feature which remains being the weak refractility of the cells. The picture both in wet mounts and in stained preparations is strongly suggestive of a small, non-motile, Gram-negative true bacterium.' Gibson (1955) noted that certain soil organisms, closely resembling the cytophagas in many respects, did not move by means of the gliding motility which is held to be diagnostic of the myxobacteria. This difficulty was also experienced by one of us (P.R.H.) when making a detailed study of 62 marine bacteria, all but one of which had been labelled Flavobacterium by the workers who isolated them. By using orthodox taxonomic methods, it was concluded that some of the test organisms were probably cytophages, though others had been properly assigned to the flavobacteria (Hayes, 1962). However, these conclusions were far from being unequivocal and it was thought that the application of Adansonian methods might help to solve this problem and, at the same time, provide an interesting comparison between different taxonomic techniques.

Present addresses: * Marine Science Laboratories, Menai Bridge, Anglesey. $\dagger$ Birds Eye Foods Limited, South Denes, Great Yarmouth, Norfolk. 


\section{METHODS}

The sixty-two isolates used in this work were of marine origin, and all except NCMB 11 had been identified as Flavobacterium species by the workers who isolated them; isolate NCMB 11 was labelled as a presumptive Cytophaga. All the isolates were examined for a large number of characters; details of the methods used were reported previously (Hayes, 1962).

The data on the characters of the organisms were resolved into 104 features, and put in a form suitable for feeding into a computer. The features ranged over morphology, cultural characters, biochemical reactions and nutrition. The data were processed by an Elliot 402 computer, using Sneath's (1957) programme.

\section{RESULTS}

A diagrammatic representation of the sorted $S$ values is shown in Fig. 1 . It is clear that in terms of overall similarity as determined by the formula $S=n_{s} / n_{s}+n_{d}$, the organisms examined fell into two large groups or pleista (A, G), several smaller pleista $(F, T, L)$ while the remaining isolates differed widely from each other in their $S$ values, that is, they were the sole representative of their pleiston present. Pleiston G consists of an inner cluster and an outer array of somewhat less similar organisms. The position of the bottom boundary of pleiston $G$ has been somewhat arbitrarily drawn between NCMB 287 and 277 (see Fig. 1). It could also have been drawn so as to include one or more organisms lower down the list. If the view is taken that boundaries of this type are not facts of nature, but merely convenient devices (Floodgate, 1962) then it follows that the best line will be the one which serves the greatest number of bacteriological purposes. At the moment, it is not possible to state which of the possible boundary lines is the most satisfactory, hence an arbitrary decision has to be made. The term pleiston (pl. pleista), referring to a cluster of similar organisms, was coined by Sneath (1957) and is preferred to 'groups' or 'species' because both these terms have specialized taxonomic meanings laid down in the International Code of Bacterial Taxonomy and Nomenclature (Judicial Commission, 1958).

\section{Description of the pleista and diagnostic features}

To identify a new isolate as a member of pleiston A or $\mathbf{G}$ with certainty it would be necessary to calculate its $S$ value with respect to the established members of the pleiston. However, if the isolate possesses all or most of the characters of either A or G, the probability of it belonging to the one or the other pleiston is very high. The characters of both pleista and the frequency of their occurrence are set out in Table 1, and those which occur most frequently can be thought of as diagnostic. In so far as they possess most of the diagnostic characters NCMB 245 and NCMB 262 can be said to be typical strains of pleiston A and G respectively. Furthermore, the average of their similarity $(S)$ values to each of the other strains within the pleiston is very high, suggesting that they are very similar to the others in very many respects. 


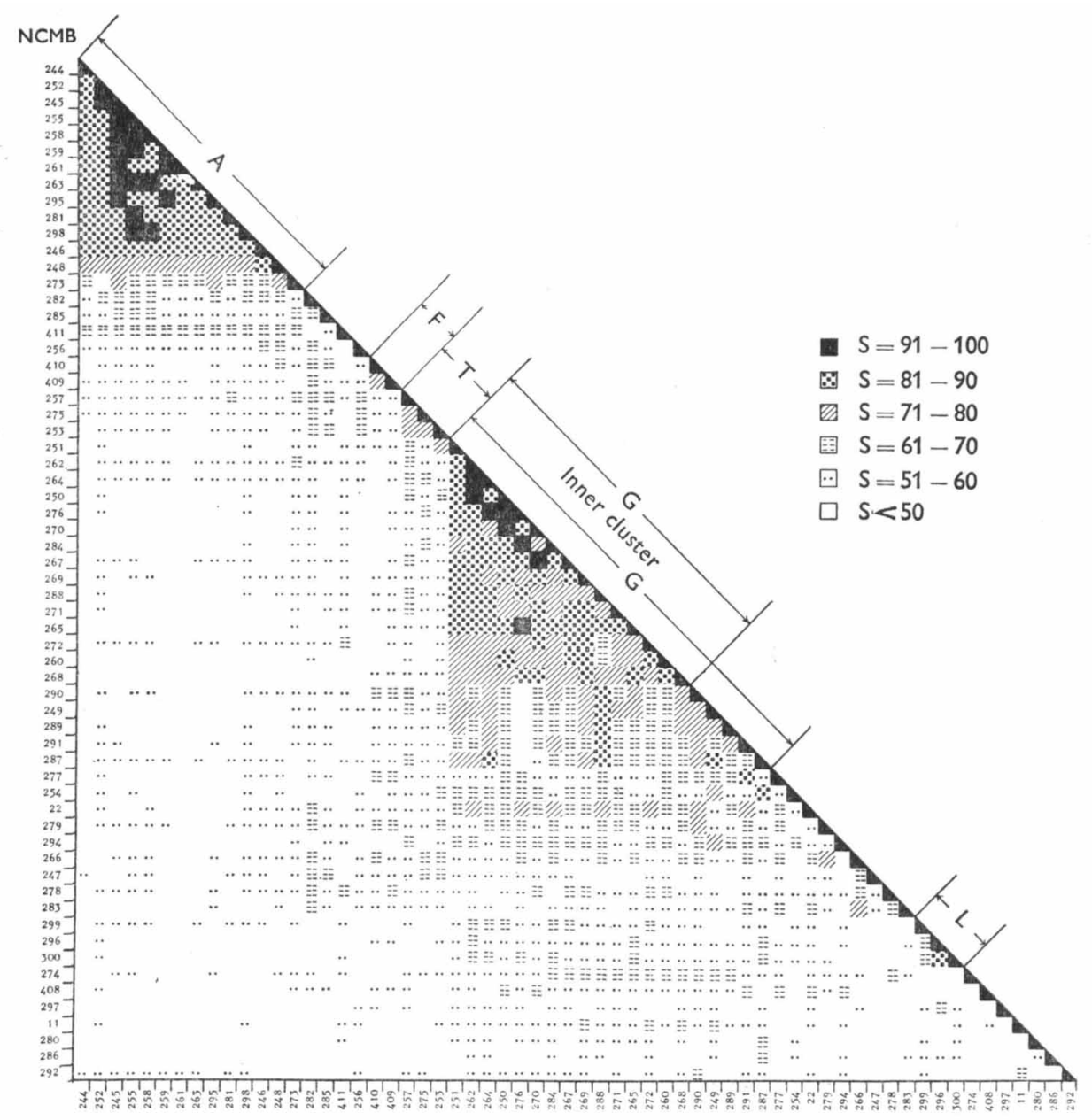

Fig. 1. Diagrammatic representation of sorted $S$ values.

\section{DISCUSSION}

Having established the pleista, it is natural to inquire whether any of them resemble any well established bacterial genera or species although a pleiston ought not to be equated to any other taxon. The possibility that the organisms which make up pleiston A or G would also fall into the genus Flavobacterium of Bergey's Manual (1957), the genus Pseudobacterium of Krassilnikov (1949) or to the genus Cytophaga described in both these works, is discussed below. It must be emphasized that each of these classifications is based upon a different taxonomic principle so that it would be surprising if each method should lead to the same arrangement of the organisms. Krassilnikov (1949) classified bacteria by what he believed to be their phylogeny. Bergey's Manual (1957), being concerned with bringing together and co-ordinating the work of a large number of bacteriologists, reflects several taxonomic viewpoints, whereas pleista $\mathbf{A}$ and $\mathbf{G}$ are comprised of organisms which are alike in their over-all similarity. Fortunately, however, the concept of similarity, although not 
expressed mathematically, is frequently used by the authors of Bergey's Manual (1957), while phylogenetically close organisms are often similar to each other; whence some approximation between the pleista and the genera of Bergey's Manual (1957) or Krassilnikov may exist. When Bergey's Manual (1957) is consulted, pleiston $\mathrm{G}$ is found to resemble the genus Flavobacterium, in that the cultures consist of medium sized rods, forming an orange or yellow pigment, and attacking sugars either feebly or not at all. This pleiston can be further associated with Section I of the key to the genus Flavobacterium since they are non-motile, modify litmus milk and liquefy gelatin. Thereafter, when division is largely made on the kind of reaction to litmus milk, the key becomes unworkable. Three pleiston $\mathbf{G}$ organisms did not change milk, 16 reduced the indicator, 10 formed alkali or peptonized the casein, 2 took on a slightly acid reaction and 1 formed a clot. Most organisms carried out several of these reactions simultaneously. The fact that these very similar strains differed in their reaction to litmus milk suggests that a division into several species by means of this test is not advisable. The nomenclatural type species of the genus Flavobacterium, F. aquatile ATCC 11947 was not included

\section{Table 1. Characters of pleista $A$ and $G$}

\begin{tabular}{|c|c|c|c|c|}
\hline & & & $\begin{array}{r}\text { Number } \\
\text { possess } \\
\text { charac }\end{array}$ & $\begin{array}{l}\text { f strains } \\
\text { ng the } \\
\text { ers in }\end{array}$ \\
\hline \multicolumn{3}{|c|}{ Characters of organisms } & $\begin{array}{r}\text { leiston A } \\
\text { (total 14 } \\
\text { strains) }\end{array}$ & $\begin{array}{c}\text { Pleiston G } \\
\text { (total 20 } \\
\text { strains) }\end{array}$ \\
\hline Sides of organisms & \multicolumn{2}{|c|}{$\begin{array}{l}\text { Parallel } \\
\text { Bulging } \\
\text { Irregular }\end{array}$} & $\begin{array}{r}14 \\
\mathbf{0} \\
\mathbf{0}\end{array}$ & $\begin{array}{r}8 \\
11 \\
1\end{array}$ \\
\hline Regularity of morphology* & \multicolumn{2}{|c|}{$\begin{array}{l}\text { Monomorphic } \\
\text { Pleomorphic }\end{array}$} & $\begin{array}{r}14 \\
0\end{array}$ & $\begin{array}{r}0 \\
20\end{array}$ \\
\hline Insoluble pigment & \multicolumn{2}{|c|}{$\begin{array}{l}\text { Yellow } \\
\text { Green-yellow } \\
\text { Orange-yellow }\end{array}$} & $\begin{array}{l}\mathbf{5} \\
\mathbf{9} \\
\mathbf{0}\end{array}$ & $\begin{array}{r}6 \\
0 \\
14\end{array}$ \\
\hline Growth in broth & \multicolumn{2}{|c|}{$\begin{array}{l}\text { Granular ring } \\
\text { Pellicle } \\
\text { Granular, easily dispersed deposit } \\
\text { Flocculent deposit, dispersed with } \\
\text { difficulty }\end{array}$} & $\begin{array}{r}12 \\
2 \\
12 \\
2\end{array}$ & $\begin{array}{r}\mathbf{9} \\
\mathbf{0} \\
\mathbf{0} \\
\mathbf{1 5}\end{array}$ \\
\hline $\begin{array}{l}\text { Lowest temperature per- } \\
\text { mitting growth }\end{array}$ & \multicolumn{2}{|c|}{$\begin{array}{l}0^{\circ} \\
5^{\circ} \\
10^{\circ}\end{array}$} & $\begin{array}{r}14 \\
0 \\
0\end{array}$ & $\begin{array}{r}13 \\
\mathbf{3} \\
4\end{array}$ \\
\hline $\begin{array}{l}\text { Highest temperature per- } \\
\text { mitting growth* }\end{array}$ & \multicolumn{2}{|l|}{$\begin{array}{l}30^{\circ} \\
\mathbf{2 5}^{\circ}\end{array}$} & $\begin{array}{r}13 \\
1\end{array}$ & $\begin{array}{r}1 \\
19\end{array}$ \\
\hline Optimum temperature & \multicolumn{2}{|c|}{$\begin{array}{l}\mathbf{2 0 ^ { \circ }} \\
\mathbf{2 1 - 2 4 ^ { \circ }} \\
25^{\circ}\end{array}$} & $\begin{array}{r}0 \\
14 \\
\mathbf{0}\end{array}$ & $\begin{array}{r}19 \\
0 \\
1\end{array}$ \\
\hline Heat resistance* & $\begin{array}{l}55^{\circ} \\
45^{\circ}\end{array}$ & $\begin{array}{l}\text { No. killed in } 15 \mathrm{~min} \text {. } \\
\text { No. surviving } 15 \mathrm{~min} \text {. but not } 30 \mathrm{~min} \text {. } \\
\text { No. killed in } 15 \mathrm{~min} \text {. } \\
\text { No. surviving } 15 \mathrm{~min} \text {. but not } 30 \mathrm{~min} \text {. } \\
\text { No. surviving } 30 \mathrm{~min} \text {. but not } 45 \mathrm{~min} \text {. } \\
\text { No. surviving } 45 \mathrm{~min} \text {. } \\
\text { No. killed in } 24 \mathrm{hr} \text {. } \\
\text { No. surviving } 24 \mathrm{hr} \text {. but not } 48 \mathrm{~min} \text {. } \\
\text { No. surviving } 48 \mathrm{hr} \text {. }\end{array}$ & $\begin{array}{r}\mathbf{9} \\
\mathbf{5} \\
\mathbf{0} \\
\mathbf{0} \\
\mathbf{0} \\
\mathbf{1 4} \\
\mathbf{0} \\
\mathbf{0} \\
\mathbf{1 4}\end{array}$ & $\begin{array}{r}20 \\
0 \\
8 \\
9 \\
2 \\
2 \\
16 \\
2 \\
2\end{array}$ \\
\hline
\end{tabular}


Table 1 (cont.)

Characters of organisms

\begin{tabular}{|c|c|c|c|}
\hline $\mathrm{NaCl}$ tolerance & $\begin{array}{l}\text { No. tolerating } 2 \% \text { but not } 4 \% \\
\text { No. tolerating } 4 \% \text { but not } 6 \% \\
\text { No. tolerating } 6 \% \text { but not } 10 \% \\
\text { No. tolerating } 10 \%\end{array}$ & $\begin{array}{r}0 \\
1 \\
13 \\
0\end{array}$ & $\begin{array}{r}1 \\
0 \\
18 \\
1\end{array}$ \\
\hline Penicillin sensitive & - & 14 & $\mathbf{9}$ \\
\hline Streptomycin sensitive & - & 14 & 16 \\
\hline Vibriostat sensitive* & 一 & 14 & $\mathbf{1}$ \\
\hline Gelatin liquefaction* & $\begin{array}{l}\text { Incomplete liquefaction in } 2-4 \text { weeks } \\
\text { Complete liquefaction in } 2-3 \text { weeks }\end{array}$ & $\begin{array}{r}12 \\
0\end{array}$ & $\begin{array}{r}1 \\
15\end{array}$ \\
\hline Ammonia from peptone* & $\begin{array}{ll}2 & -\end{array}$ & $\mathbf{0}$ & 20 \\
\hline Acid from & $\begin{array}{l}\text { Xylose* } \\
\text { Rhamnose* } \\
\text { Glucose* } \\
\text { Fructose* } \\
\text { Mannose* } \\
\text { Galactose } \\
\text { Sucrose* } \\
\text { Maltose* } \\
\text { Mannitol* } \\
\text { Salicin }\end{array}$ & $\begin{array}{r}14 \\
12 \\
14 \\
14 \\
14 \\
7 \\
14 \\
12 \\
13 \\
9\end{array}$ & $\begin{array}{l}0 \\
0 \\
0 \\
0 \\
0 \\
0 \\
0 \\
0 \\
0 \\
0\end{array}$ \\
\hline Litmus milk & $\begin{array}{l}\text { Reduction of indicator } \\
\text { Acid reaction } \\
\text { Alkaline reaction } \\
\text { Peptonization } \\
\text { Clot }\end{array}$ & $\begin{array}{l}\mathbf{1} \\
\mathbf{3} \\
\mathbf{1} \\
\mathbf{0} \\
\mathbf{0}\end{array}$ & $\begin{array}{r}16 \\
2 \\
6 \\
4 \\
1\end{array}$ \\
\hline 'Oxidase' & - & $\mathbf{0}$ & 9 \\
\hline Starch hydrolysis & 一 & $\mathbf{1}$ & $\mathbf{5}$ \\
\hline Tributyrin agar & - & 6 & 1 \\
\hline Nutrition* & $\begin{array}{l}\text { Requiring unknown factors in sea-water } \\
\text { broth } \\
\text { Growth in defined media plus growth } \\
\text { factors } \\
\text { Growth in defined media plus amino } \\
\text { acids } \\
\text { Growth in defined media plus purines }\end{array}$ & 12 & 10 \\
\hline 'Swarming'* & $\begin{array}{l}\text { Swarm at peptone concentrations of } \\
0.25 \% \\
\text { Swarm at peptone concentrations of } \\
0.05 \% \\
\text { Swarm at peptone concentrations of } \\
0.01 \% \\
\text { Did not swarm }\end{array}$ & 10 & 20 \\
\hline
\end{tabular}

The cells of pleiston A strains measured 1-5 $\mu \times 0.4-0.6 \mu$ with most strains $1-3 \mu \times 0.4-0.6 \mu$; the cells of pleiston $\mathrm{G}$ strains measured $1->10 \mu \times 0.4-1.0 \mu$ with most strains $1-5 \mu \times 0.5-0.8 \mu$.

All strains were composed of Gram negative, non-motile rods. All colonies were circular, smooth, shiny, translucent and with an entire edge when grown on sea-water nutrient agar, all grew with a uniform turbidity in broth; all were sensitive to chloramphenicol and terramycin; none produced nitrite from nitrate; all produced $\mathrm{H}_{2} \mathrm{~S}$; none formed acid from arabinose, lactose, trehalose, raffinose, starch, insulin, dulcitol, sorbitol or inositol. All were catalase positive and none used citrate as sole carbon source.

* Indicates those characteristics which distinguish the pleista and can be used for identification. 
in the computer analysis because sufficient data on this strain were not available. However, some of the morphological, cultural and biochemical characters of the type strain have been examined by one of us (P.R.H.), and found to be such as to suggest that this strain might well fall into pleiston $G$. This is further evidence for the proposition that the genus Flavobacterium and pleiston $\mathbf{G}$ are conformable.

The only other genus with which pleiston $\mathrm{G}$ is at all likely to be associated is the genus Alcaligenes. However, this is not as plausible as associating pleiston $\mathrm{G}$ with the flavobacteria because although Alcaligenes species have some biochemical properties similar to those of members of pleiston $G$, the production of yellow pigments by Alcaligenes is not very common. Furthermore, the organisms of pleiston $G$ tend to be orange-yellow rather than brown or grey-yellow as the Alcaligenes group are.

It is difficult to find a taxon among the true bacteria in the scheme of Bergey's Manual (1957) which resembles pleiston A. They are yellow pigmented, but the pigments tend to be greenish yellow rather than yellow or orange. Acid was formed from a high percentage of the carbohydrates examined, and the organisms were not very proteolytic. These characteristics would not necessarily dissociate them from the genus Flavobacterium, particularly as several of the species listed in Bergey's Manual (1957) also form acid from a number of sugars.

When the organisms of pleista $\mathbf{A}$ and $\mathbf{G}$ are compared with Krassilnikov's classification (1949), both can be associated with the genus Pseudobacterium. These strains are described by Krassilnikov as having rod-shaped cells of varying size, sometimes pleomorphic and occasionally decomposing into short elements of coccoid forms; they are non-motile and may be Gram-positive or Gram-negative; the colonies are colourless, red, yellow or orange. Physiologically they are heterogeneous. Clearly pleista $\mathbf{A}$ and $\mathbf{G}$ could be associated with this genus.

The question remains whether either pleiston $\mathbf{A}$ or $\mathbf{G}$ can be allied to the genus Cytophaga. The main characters of this genus as described by Bergey's Manual (1957) are briefly as follows: weakly refractile flexible rods; reproduction by binary transverse fission; absence of fruiting bodies; movement is by a gliding motion over a surface giving rise to a swarm or pseudoplasmodium of a flat, thin, spreading mass of vegetative organisms. The type species of the genus is Cytophaga hutchinsonii, a culture which is not now available. The attributes of the 62 isolates examined in the present work with regard to the first three of these characters were not available for inclusion in the Adansonian analysis; they were referred to in a previous paper (Hayes 1962): The ability to swarm was, however, included in the analysis. Hayes (1962) confirmed the observation of Stanier (1947) that there was a relationship between peptone concentration and motility, and showed that a number of the strains under study could be induced to form a swarm when the peptone concentration was lowered sufficiently. He suggested that the formation of a swarm on a peptone-depleted agar medium constituted a sensitive method of demonstrating a gliding motility which is too slow to be observed microscopically in a wet film preparation. When pleiston $\mathrm{G}$ was examined it was found that none of its constituent isolates showed any sign of swarming at any of the peptone concentrations used, while all but 2 of the 14 strains of pleiston $A$ did so. It would be reasonable then to consider pleiston $A$ as bearing a resemblance to the genus Cytophaga. 
Unfortunately some other swarmers did not fall into pleiston $\mathbf{A}$, including the two most vigorous ones, NCMB 11 and 292, both of which were also seen to move by gliding when observed under the microscope. Indeed these two organisms have a low $S$ value when compared to almost all the other cultures, although they are similar to each other $\left(S_{11-292}=69 \%\right)$. Other swarmers were NCMB 247 and 285 , and NCMB 253, 257 and 275, the latter three forming pleiston $T$. The pair NCMB 247 and 285 are also fairly similar to each other $\left(S_{247-285}=63 \%\right)$, but did not fit into any of the pleista. It is well established that gliding motility is exhibited by many widely differing organisms, including blue-green algae, a fact which suggests that this kind of motility has arisen several times during the evolution of micro-organisms. There is no a priori reason for believing that a similar development could not occur among the true bacteria, giving rise to organisms that would in this respect closely resemble the cytophagas.

A comparison can be made between the groups formed by Hayes (1962) by traditional taxonomic methods, and the pleista formed by Adansonian techniques. Pleiston A corresponds exactly to Hayes group I. Pleiston $\mathbf{G}$ is composed of Hayes group $2+$ group 3 except NCMB 254 which fell just outside the pleiston $G$ boundary as now drawn. Also included in pleiston G are two organisms NCMB 288 and 290 which Hayes could not place in any of his groups. Three of the five members of Hayes group 4 make up pleiston $T$, the exceptions being NCMB 247 and 285, neither of which fell into any category in the computer analysis. NCMB 409 and 410 which formed pleiston F were not classified by Hayes, while мсмв 296 and 300 which he assigned to the genus Flavobacterium came together as pleiston $\mathrm{L}$ in the Adansonian analysis. However, these organisms are very unlike to the organisms of pleiston $\mathbf{G}$ which are associated with the genus Flavobacterium. It is also interesting to note that NСмB 280 and 299, both of which Hayes (1962) was able to place in the genus Corynebacterium as described in Bergey's Manual (1957), are very unlike each other when all their properties are taken into account $\left(S_{280-299}=54 \%\right)$. Similarly, NCMB 286 and 294, which can be assigned to the genus Pseudomonas by using the criteria of Shewan, Hobbs \& Hodgkiss (1960) have a low over-all similarity value to each other $\left(S_{286-294}=52 \%\right)$.

The work described in this paper was carried out as part of the programme of the Department of Scientific and Industrial Research.

\section{REFERENCES}

Bergey's Manual of Determinative Bacteriology (1957). 7th ed. Ed. by R. S. Breed, E. G. D. Murray and N. R. Smith. Baltimore: Williams and Wilkins.

Floodgate, G. D. (1962). Some remarks on the theoretical aspects of bacterial taxonomy. Bact. Rev. 26, 277.

Gibson, T. (1955). General morphology in the principles of microbial classification. J. gen. Microbiol. 12, 324.

HAYes, P. R. (1962). Studies on marine flavobacteria. J. gen. Microbiol. 30, 1.

Judicial Commission (1958). International Code of Nomenclature of the Bacteria and Viruses. Ed. by R. E. Buchanan, S. T. Cowan, T. Wiken and W. A. Clark. Iowa State University Press.

Krassilnikov, N. A. (1949). Diagnostik der Bakterien und Actinomyceten. German translation from Russian, 1959, by R. Witter and H. Dicksheit. Jena: Gustav Fischer Verlag. 
Shewan, J. M., Hobbs, G. \& Hodgkiss, W. (1960). A determinative scheme for the identification of certain genera of Gram-negative bacteria, with special reference to the Pseudomonadaceae. J. appl. Bact. 23, 279.

SNeath, P. H. A. (1957). The application of computers to taxonomy. J. gen. Microbiol. 17, 201.

Stanier, R. Y. (1947). Studies on non-fruiting myxobacteria. 1. Cytophaga johnsonae, n.sp., a chitin decomposing myxobacterium. J. Bact. 53, 297. 